\section{Title \\ Project 93L-EWL-097, Fire Alarm System Improvements, 300 Area}

5. Key Words

Acceptance Test Procedure, Fire Alarm System 338 Building

This document contains the Acceptance Test Procedure (ATP) which will demonstrate that the modifications to the Fire Protection systems in the 338 Building function as intended. The ATP will test the fire alarm control panel, flow al arm pressure switch, post indicator valve tamper switch, heat detectors, flow switches, and fire alarm signaling devices.
3. Number

WHC-SD-L097-ATP-005

6. Author

Name: M. V. Scott

signature

Organization/Charge Code
4. ReV No.

0

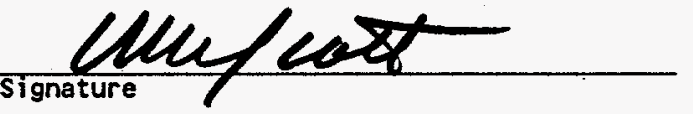

8. PURPOSE AND USE OF DOCUMENT - This document was prepared for use with in thy U.S. Department of Energy and its contractors. It is to be used dkly to perform, direct, or integrate work under U.S. Department of Energy contracts. This document is not approved for public release until reviewed.

PATENT STATUS - TAis document copy, since it is transmitted in advance of patent clearance, is made available/n confidence solely for use in performance of work under/contracts with the U.S. Department of Energy. This document is not to be published nor its contents otherwise disseminated or ysed for purposes other than specified above before patenk approvo $\chi$ for such release or use has been secured, upon request, frdp tho Patent Counsel, U.S. Department of Energy Field office, Richland WA.

DISCLAIMER - This report yas prepared as an account of work sponsored by an agency of the United States Government. Neither the United States Government fror any agendx thereof, nor any of their employees, nor any of their contractors subcontractors or their employees, makes any farranty, express or implied, or assunes any legal liability or responsibility for the accuracy, completeness, or any third party's use or the results of such ust of any information, apparatus, prodyet, or process disclosed, or represents that its use would not infringe privately owned rights. Reference herein to any specific commercial product, process, or service by trade name, trademark manufacturer, or otherwise, does no necessarily constityte or imply its endorsement, recommendation, on favoring by the yuited states Government or any agency thered or its contuactors or subcontractors. The views and opinions of authors expfessed herein do not necessarily state or reflect those of the United States Government or any agency thereof.

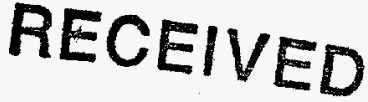

JAN 241995

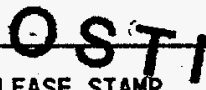

10.

RELEASE STAMP

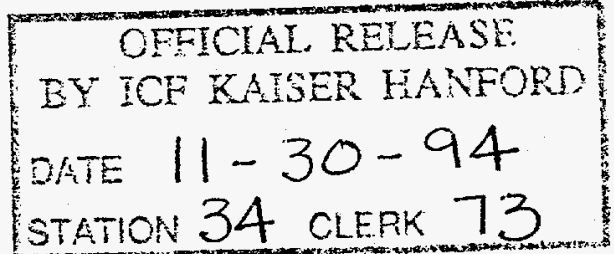

9. Impact Level $\mathrm{SQ}$

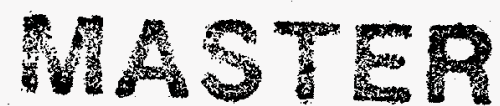




\section{DISCLAIMER}

Portions of this document may be illegible in electronic image products. Images are produced from the best available original document. 


\section{RELEASE AUTHORIZATION}

Document Number: WHC-SD-L097-ATP-005, Rev. 0

Document Title:

Project 93L-EWL-097, Fire Alarm System Improvements, 300 Area

Release Date: $\quad 1 / 10 / 95$

\section{This document was reviewed following the procedures described in WHC-CM-3-4 and is:}

\section{APPROVED FOR PUBLIC RELEASE}

WHC Information Release Administration Specialist:
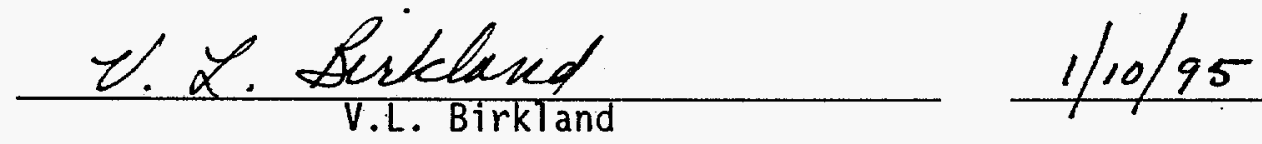

TRADEMARK DISCLAIMER. Reference herein to any specific commercial product, process, or service by trade name, trademark, manufacturer, or otherwise, does not necessarily constitute or imply its endorsement, recomendation, or favoring by the United States Government or any agency thereof or its contractors or subcontractors.

This report has been reproduced from the best available copy. Available in paper copy and microfiche. Printed in the United States of America. Available to the U.S. Department of Energy and its contractors from:

U.S. Department of Energy

Office of Scientific and Technical Information (OSTI)

P.0. Box 62

Oak Ridge, TN 37831

Telephone: (615) 576-8401

Available to the public from:

U.S. Department of Commerce National Technical Information Service (NTIS) 5285 Port Royal Road

Springfield, VA 22161

Telephone: (703) $487-4650$

\section{DISCLAIMER}

This report was prepared as an account of work sponsored by an agency of the United States Government. Neither the United States Government nor any agency thereof, nor any of their employees, makes any warranty, express or implied, or assumes any legal liability or responsibility for the accuracy, completeness, or usefulness of any information, apparatus, product, or process disclosed, or represents that its use would not infringe privately owned rights. Reference herein to any specific commercial product, process, or service by trade name, trademark, manufacturer, or otherwise does not necessarily constitute or imply its endorsement, recommendation, or favoring by the United States Government or any agency thereof. The views and opinions of authors expressed herein do not necessarily state or reflect those of the United States Government or any agency thereof. 
ACCEPTANCE TEST PROCEDURE WHC-SD-L097-ATP-005

TEST TITLE Fire Alarm System

LOCATION Building 338,300 Area

PROJECT NUMBER L-097

WORK ORDER CR9963

PROJECT TITLE F.ire Alarm System Improvements

Prepared By

ICF Kaiser Hanford Company

Richland, Washington

For the U.S. Department of Energy

Contract DE-ACO6-93RLL12359

PROCEDURE APPROVAL

ICF KAISER HANFORD COMPANY (ICF KH)

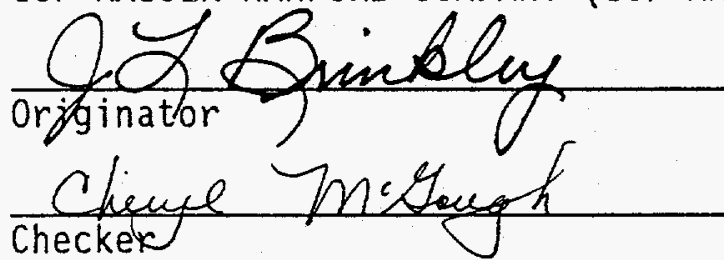

N/A

Environmental

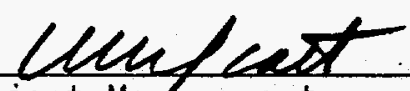

Project Mapagement

Westinghouse Hanford Company (WHC)

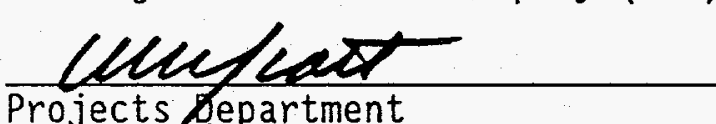

Projects department

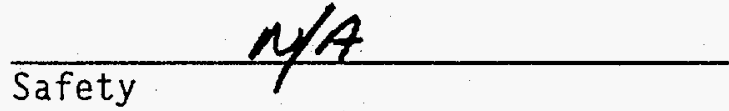

wM.kwigie Ra.Fishes for Hanford Fire Department.

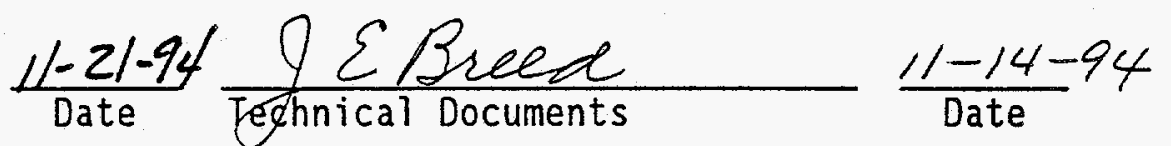

$\frac{11.22 .94}{\text { Date }} \frac{C \cdot d . \text { Egen }}{\text { Safety }} \frac{11 / 2 z / 94}{\text { Date }}$

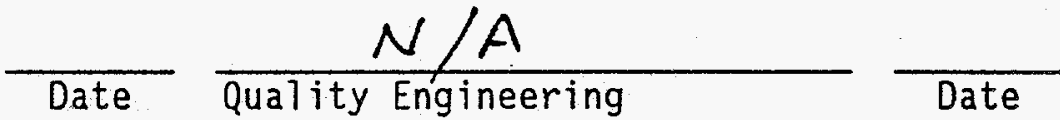

$11 / 2 \& / 8 \Omega$

Date
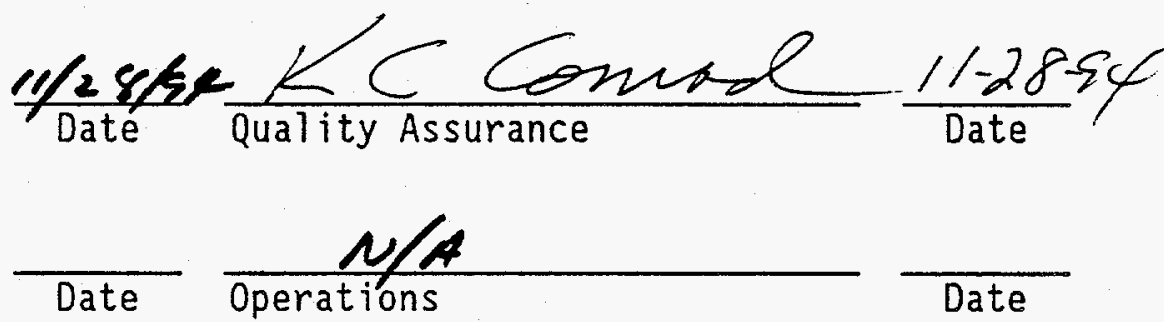

Date

$\frac{11-23-94}{\text { Date }}$

OFICEAL KELEASE

BY ICF KAISER HAWPORD

DATE $11-30-94$

STATION 34 CLERK 73 
EXECUTED BY

Test Director/Organization

Date Test Operator/Organization

Date

Recorder/Organization

Date

WITNESSES

Witness/Organization

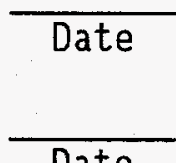

$$
\text { Tit7e III Inspector }
$$

Date

Witness/Organization

Date

Witness/Organization

Date

A-E APPROVAL

ICF Kaiser Hanford Company (ICF KH)

Without

exceptions

With exceptions resolved
With exceptions

outstanding

Acceptance Inspection

Project Manager

Date

TEST APPROVAL AND ACCEPTANCE

Westinghouse Hanford Company

Without

exceptions

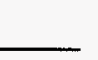
With exceptions
resolved
With exceptions

outstanding

<Title or Department>

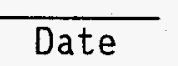

<Title or Department>

Date

<Title or Department

Date

<Title or Department>

Date 
TITLE/PROCEDURE APPROVAL

EXECUTION AND TEST APPROVAL

$\begin{array}{ll}\text { TABLE OF CONTENTS } & 3\end{array}$

$\begin{array}{ll}1 \text { PURPOSE } & 4\end{array}$

2 REFERENCES $\quad 4$

3 RESPONSIBILITIES $\quad 4$

4 CHANGE CONTROL $\quad 7$

5 EXECUTION $2{ }^{\circ} 7$

6 EXCEPTIONS $\quad 8$

7 PREREQUISITES, EQUIPMENT REQUIRED, AND ABBREVIATIONS 9

$8 \quad$ FIRE ALARM SYSTEM TEST 11

\begin{tabular}{l|r}
9 & GENERAL ALARM FUNCTIONS
\end{tabular}

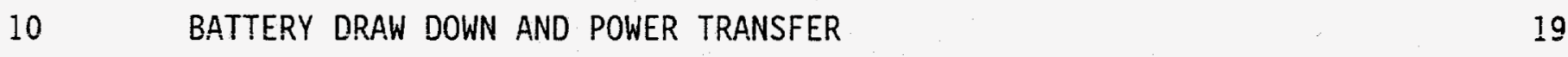

11 FCP GROUND FAULT_DETECTION 21

12 SECURE FROM TEST 22

$\begin{array}{ll}\text { EXCEPTION FORM } & 23\end{array}$

NOTE: At completion of test, enter pages added during performance of test to this Table of Contents. 
This Acceptance Test Procedure (ATP) has been prepared to demonstrate that the modifications to the Fire Protection systems function as required by project criteria. The ATP covers Building 338.

The ATP will test the fire alarm control panels (FCP), flow alarm pressure switch (FL), post indicator valve tamper switch (PIV TS), outside screw and yoke valve tamper switch (OS\&Y TS), and fire alarm signaling devices.

NOTE: The tests may be run without completing entire section before proceeding to the next.

2

2.1

2.2

2.3

3

3.1

3.2

\section{REFERENCES}

\section{DRAWINGS}

H-3-304602, Sh 1-2, Rev 0 Fire Protection - Alarm and Detection Floor Plan H-3-304603, Sh 1-2, Rev 0 Fire Protection - Alarm and Detection Diagrams, Details \& Schedule

SPECIFICATION

L-097-C5, Rev $0 \quad$ Construction Specification

Engineering Change Notices (ECN)

Prior to final test approval, enter ECNs written against this ATP.

\section{RESPONSIBILITIES}

\section{GENERAL}

Each company or organization participating in this ATP will designate personnel to assume the responsibilities and duties as defined herein for their respective roles. The designees shall become familiar with this ATP and the systems involved to the extent that they can perform their assigned duties.

WHC PROJECT ENGINEER

\subsubsection{Designates a Test Director.}

3.2.2 Coordinates testing of fire alarm system with the Hanford Fire Department and building management. Ten day written notification (DSI) required for scheduling.

3.2.3 Acts as liaison between the participants in acceptance testing.

3.2.4 Distributes the approved testing schedule 1 week before start of testing. 
3.2 .5

3.2 .6

3.2 .8

3.2 .9

3.2.10

3.2 .11

3.2 .12

3.3

\section{TEST DIRECTOR}

3.3 .1

3.3 .2

3.3 .3

3.3 .4

$3 . \overline{3} .5$

3.3 .6

3.3 .7

3.3 .8

3.3 .9

3.3 .10

3.3 .11

3.3 .12
Coordinates and directs acceptance testing.

Schedules and conducts a pretest kickoff meeting with test participants before start of testing.

Notifies the persons performing and witnessing the test 2 days before the start of testing.

Notifies concerned parties when a change is made in the testing schedule.

Signs Execution and Test Approval page when test is approved and accepted.

Takes necessary action to clear exceptions to the test.

Signs Exception form when exception has been resolved.

Provides a distribution list for the approved and accepted ATP.

Schedules dry run of the ATP (pre-test).

Confirms that Field testing and inspection of the system or portion of the system to be tested has been completed.

Stops any test which, in his or her judgment, may cause damage to the system until the problem has been resolved.

After verifying there is no adverse impact, may alter the sequence in which systems or subsystems are tested.

Ensures that required environmental conditions are maintained.

If a test is to be suspended, reverifies and documents the prerequisites before restarting the test.

Initiates ECNs to document required changes to the ATP.

Reviews recorded data, discrepancies, and exceptions.

Obtains information or changes necessary to clear or resolve objections during the performance of the test.

Signs Execution Test and Approval page when test has. been performed.

Signs Exception form when exception has been resolved.

Obtains required signatures on the ATP Master prior to reproduction and distribution. 
Notifies the Hanford Fire Department before each testing day that the tests will begin on time or that the tests will be delayed. Gives the expected time of delay when possible.

3.3.14 Assures the safety of activities within the test area to prevent personnel injury or property damage.

3.4 WITNESSES (Provided by Participating Organizations. One witness shall be a Title III acceptance inspector.)

3.4.1 Witness the tests.

3.4.2 Evaluate results of testing.

3.4.3 Assist the Test Director when requested.

3.4.4 Sign Execution and Test Approval page when test has been performed.

3.4.5 Sign Exception form when exception has been resolved.

3.5 RECORDER (Provided by ICF KH)

3.5.1 Prepares a Field copy from the ATP Master.

3.5.2 Records names of all designated personnel on Field copy of ATP prior to start of testing.

3.5.3 Observes tests and records test data.

3.5.4 Signs Execution and Test Approval page.

3.5.5 Initials and dates every test step on the Field copy as it is completed next to the step number or on a data sheet, when provided. On data sheets where there is not room for both the initial and date, date may be entered at bottom of column.

3.5.6 Records objections and exceptions on an Exception form. Transfers information in ink or type to an Exception form Master. Uses additional Exception forms as needed.

3.5.7 Signs Exception form when exception has been resolved.

3.5.8 Notifies the Test Director at time the objection is made.

3.5.9 Assigns alpha numeric page numbers to added data sheets and Exception forms, after test is finished. Records page numbers in the Table of Contents.

3.5.10 Transfers changes and the final test results with Recorder's signature and dates for each step to the Master in ink or type. Submits the completed Master to the Test Director for approval signature routing. Transmits the Field copy to Construction Document Control for inclusion in the official project file. 
3.6.1 Performs test under direction of the Test Director.

3.6.2 Confirms that all equipment required for performing test will be available at the start of testing.

3.6.3 Provides labor, equipment, and test instruments required for performing tests which have not been designated as being provided by others.

3.6.4 Requests in writing from the Test Director those services, materials, or equipment that have been designated as being supplied by others.

3.6.5 Signs the Execution and Test Approval page.

3.7 DESIGN ENGINEER AND ACCEPTANCE INSPECTION

3.7.1 Evaluate results of testing.

3.7.2 Sign for A-E Approval on Execution and Test Approval page.

Required changes to this ATP must be processed on ECNs in accordance with company procedures. If a need for change is discovered in the course of running the test, the test shall be stopped until the ECN is approved. However, this does not prevent the running of another portion of the test unaffected by the change.

5

\section{EXECUTION}

\subsection{OCCUPATIONAL SAFETY AND HEALTH}

Individuals shall carry out their assigned work in a safe manner to protect themselves and others from undue hazards and to prevent damage to property and environment. Facility line managers shall assure the safety of activities within their areas to prevent injury, property damage, or interruption of operation. Performance of test activities shall always include safety and health aspects.

5.2 PERFORMANCE

5.2.1 Perform test following the steps and requirements of this procedure.

5.2.2 Conduct testing in accordance with ICF KH procedure CON 3.5 (Performance and Recording of Acceptance Test Procedures).

NOTE: Tests may be run without completing an entire section before proceeding to the next. 
Exceptions to the required test results are sequentially numbered and recorded on individual Exception forms. This enables case-by-case resolution and approval of each exception.

Errors in the ATP itself shall NOT be processed as test exceptions (see Section 4.0).

6.2 RECORDING

6.2.1 Number each exception sequentially as it occurs and record it on an Exception form.

6.2.2 Enter name and organization of objecting party for each exception.

6.2.3 Enter planned action to resolve each exception when such determination is made.

6.3 RETEST/RESOLUTION

Record the action taken to resolve each exception. Action taken may not be the same as planned action.

6.3.1 When action taken results in an acceptable retest, sign and date Retest Execution and Acceptance section of the Exception form.

6.3.2 When action taken does not involve an acceptable retest, strike out the Retest Execution and Acceptance section of the Exception form.

6.4 APPROVAL AND ACCEPTANCE

The customer Project Engineer provides final approval and acceptance of exceptions by checking one of the following on Exception form:

6.4.1 Retest Approved and Accepted: Applicable when Retest Execution and Acceptance section is completed.

6.4.2 Exception Accepted-As-Is: Requires detailed explanation.

6.4.3 Other: Requires detailed explanation.

The customer Project Engineer signs and dates the Exception form and obtains other customer internal approvals, if required.

\subsection{DISTRIBUTION}

A copy of the approved Exception form is distributed to each participant. The signed original is attached to the ATP Master. 
The following conditions shall exist at the start of the testing for that portion of the system being tested.

7.1.1 Systems have been inspected for compliance with construction documents.

7.1.2 Reference documents (including this ATP) have been verified for correct revision number and outstanding ECNs.

7.1.3 Power is available.

7.1.4 Test instruments have a valid calibration stamp attached. Test instrument identification numbers and calibration expiration dates have been recorded.

7.1.5 Water is available to the sprinkler system.

7.1.6 Methods of water disposal have been approved by Facilities Management.

7.1.7 A pre-test has been performed to ensure system is installed correctly before formal ATP.

7.1.8 Battery fully charged (has been on charger for at least 48 hours within past week).

7.1.9 Test has been coordinated with the Hanford Fire Department.

7.1.10 A Prejob Safety Analysis has been prepared and a Prejob Safety Meeting has been conducted.

7.2 EQUIPMENT AND INSTRUMENTS

Supplied by the Test Operator unless otherwise noted.

7.2.1 Portable Voltohmmeters (VOM): Minimum range zero to $50 \mathrm{~V}$ dc and 0 to 1 megohm.

Instrument No. Expiration Date

7.2.2 Portable Ammeter: Recommended range 0 to 20 amperes.

Instrument No. Expiration Date

7.2.3 Shorting jumpers.

7.2.4 Calculator 


\section{3}

ABBREVIATIONS AND DEFINITIONS

ADM

Administration

DSI

Don't Say It (memo form)

ECN

Engineering Change Notice

EOLC

End of Line Capacitor

EOLR

End of Line Resistor

FCP

Fire Alarm Control Panel

$\mathrm{FL}$

Flow Alarm Pressure Switch

LED

Light Emitting Diode

MS

Manual Pull Station

OS\&Y

Outside Screw and Yoke.

PIV

Post Indicator Valve

RFAR

Radio Fire Alarm Reporting Box

TB

Terminal Block

TS

Tamper (Supervisory) Switch 
Perform/verify the following steps.
8.1 .1
Al1 prerequisites of Subsection 7.1 have been met.

8.1 .2

Request the HFD dispatcher bypass all signals from Box 3220 and acknowledge a 11 supervisory and alarm signals received at 200 Area Fire Station.

\subsubsection{Install RFAR door tamper switch override device.}

8.1.4 Verify FCP door is lockable and keyed with Cat 60 set key only..

8.1.5 Announce to personnel in building that a fire alarm test is in progress; evacuation is not required.

8.2 CIRCUIT SUPERVISION: This test will verify supervision of signaling devices, FL, PIV TS, OS\&Y TS, and FCP RFAR interface.

\subsubsection{Signaling Devices}

Record the following steps for the signaling devices shown on Data Sheet 8.2.1.

8.2.1.1 Lift one wire at signaling device.

8.2.1.2 Verify FCP system and audible circuit trouble LEDs on AE-3OU modules are ON and trouble buzzer is SOUNDING.

8.2.1.3 Verify "Local Panel Trouble" message for Box 3220 received at 200 Area Fire Station. Silence trouble buzzer.

NOTE: The Test Director may elect to silence the trouble buzzer at any time unless otherwise noted.

8.2.1.4 Replace wire lifted in Step 8.2.1.1 at signaling device. Reset FCP.

8.2.1.5 Verify FCP system and audible circuit LEDs are OFF. 


\begin{tabular}{|c|c|c|c|c|c|c|c|c|}
\hline \multirow[b]{3}{*}{ STEP } & \multirow[b]{3}{*}{ PERFORM/VERIFY } & ATA : & \multicolumn{2}{|c|}{8.2 .1} & & & & \\
\hline & & \multicolumn{7}{|c|}{ SIGNALING DEVICE } \\
\hline & & $51-1$ & $51-2$ & s1-3 & $\mathrm{s} 1-4$ & $\mathrm{s1-5}$ & $\mathbf{s 1 - 6}$ & $\$ 1-7$ \\
\hline 8.2 .1 .1 & $\begin{array}{l}\text { Lift one wire at } \\
\text { signaling device. }\end{array}$ & & & & & & & \\
\hline 8.2 .1 .2 & $\begin{array}{l}\text { Trouble LEDs are } \\
\text { ON. }\end{array}$ & & & & & & & \\
\hline 8.2 .1 .3 & $\begin{array}{l}\text { Trouble message } \\
\text { received at Fire } \\
\text { Station. }\end{array}$ & & NA & NA & NA & NA & NA & NA \\
\hline 8.2 .1 .4 & $\begin{array}{l}\text { Replace wire at } \\
\text { signaling device. } \\
\text { Reset FCP. }\end{array}$ & & & & & & & \\
\hline 8.2 .1 .5 & $\begin{array}{l}\text { Trouble LEDs are } \\
\text { OFF. }\end{array}$ & & & & & & & \\
\hline
\end{tabular}

8.2.2 Tamper (Supervisory) Switches

Record the following steps for the switches shown on Data Sheet 8.2.2.

8.2.2.1 Lift one wire from each switch..

8.2.2.2 Verify FCP system and FCP zone trouble LEDs are ON.

8.2.2.3 Replace wire lifted in Step 8.2.2.1. Reset FCP.

8.2.2.4 Verify FCP system and FCP zone trouble LEDs are OFF.

\begin{tabular}{|c|c|c|c|}
\hline \multicolumn{4}{|c|}{ DATA SHEET $\quad 8.2 .2$} \\
\hline \multirow[t]{2}{*}{ STEP } & \multirow[t]{2}{*}{ PERFORM/VERIFY } & \multicolumn{2}{|c|}{$\begin{array}{c}\text { ZONE TAMPER } \\
\text { (SUPERVISORY) } \\
\text { SWITCH }\end{array}$} \\
\hline & & $9-1$ & $10-1$ \\
\hline 8.2 .2 .1 & Wire lifted. & & \\
\hline 8.2 .2 .2 & Trouble LEDs are ON. & & \\
\hline 8.2 .2 .3 & Wire replaced. Reset. & & \\
\hline 8.2 .2 .4 & Trouble LEDs are OFF. & & \\
\hline
\end{tabular}


8.2.3 Post Indicator and OS\&Y TS

Record the following steps for the switches shown on Data Sheet 8.2.3.

8.2.3.1 Close valve 2 turns.

8.2.3.2 Verify FCP system and FCP zone trouble LEDs are ON.

8.2.3.3 Verify "Local Panel Trouble" message for Box 3220 received at 200 Area Fire Station.

8.2.3.4 Open valve. Reset FCP.

8.2.3.5 Verify FCP system and FCP zone trouble LEDs are OFF.

\begin{tabular}{|c|l||c|c||}
\hline \multicolumn{1}{|c|}{ DATA SHEET 8.2.3 } \\
\hline \hline STEP & \multicolumn{1}{|c|}{ PERFORM/VERIFY } & \multicolumn{2}{|c|}{ ZONE (POST INDICATOR } \\
AND OS\&Y TS)
\end{tabular}


8.2.4 Flow Alarm Pressure Switch 1-1

8.2.4.1 Lift one wire from switch.

8.2.4.2 Verify FCP system and FCP zone trouble LEDs are ON.

8.2.4.3 Replace the wire lifted in Step 8.2.4.1. Reset FCP.

8.2.4.4 Verify FCP system and FCP zone trouble LEDs are OFF.

8.2.5 Flow Alarm Pressure Switch (Wet-Pipe Sprinkler System)

8.2.5.1 Open Inspector's test valve quickly and completely.

8.2.5.2 Verify water is flowing immediately at Inspector's test valve.

8.2.5.3 Record elapsed time to system panel, signaling devices (90 seconds $\max$ )

8.2.5.4 Verify water motor gong is SOUNDING.

8.2.5.5 Verify FCP Zone 1 alarm LED is ON.

8.2.5.6 Verify RFAR "Zone IM Fire" message for Box 3220 received at 200 Area Fire Station.

8.2.5.7 Close Inspector's test valve.

8.2.5.8 Reset sprinkler system and FCP.

8.2.5.9 Verify FCP system and FCP zone alarm LEDs are OFF.

8.2.6 FCP/RFAR Interface

Record the following steps for the zones shown on Data Sheet 8.2.6.

8.2.6.1 Lift one wire from EOL device on FCP SR-35 Module (3H).

8.2.6.2 Verify RFAR zone trouble LEDS are ON.

8.2.6.3 Verify "COMM TRBL RFAR" message for Box 3220 received at area 200 Fire Station.

8.2.6.4 Replace the EOL wire lifted in Step 8.2.6.1. Reset FCP.

8.2.6.5 Verify RFAR zone trouble LEDs are OFF. 


\begin{tabular}{||c|c|c|c|}
\hline \multicolumn{3}{|c|}{ DATA SHEET 8.2.6 } \\
\hline \multicolumn{1}{|c|}{ PERFORM/VERIFY } & 1 & 2 \\
\hline \hline 8.2 .6 .1 & Lift wire. & & \\
\hline 8.2 .6 .2 & RFAR zone trouble LEDs are ON. & & \\
\hline 8.2 .6 .3 & Message received at Fire Station. & & \\
\hline 8.2 .6 .4 & Replace wire. Reset. & & \\
\hline 8.2 .6 .5 & RFAR zone trouble LEDs are OFF. & &. \\
\hline
\end{tabular}


8.3 COMBINED ALARM AND SUPERVISORY FUNCTION: This test will verify initiation circuit alarm and supervisory function.

NOTE: $\quad$ Signalling devices may be silenced after alarm message received at 200 Area Fire Station.

8.3 .1

Manual Pul1 Stations

Record the following steps for manual pull stations shown on Data Sheet 8.3.1.

NOTE: This section entails opening each manual station. Opening of the Pyrotronics MS-501 results in an alarm condition identical to the stations manual actuation.

8.3.1.1. Open MS and remove from its backbox.

8.3.1.2 Close MS. Reset FCP.

8.3.1.3 Verify FCP system and FCP zone alarm LEDs are OFF.

8.3.1.4 Lift one wire from MS.

8.3.1.5 Verify FCP zone trouble LEDs are ON.

8.3.1.6 Replace wire removed in Step 8.3.1.4.

8.3.1.7 Verify FCP zone trouble LED is OFF.

8.3.1.8 Rep?ace MS on its backbox.

8.3.1.9 Reset FCP. Verify clear of alarm.

8.3.1.10 Trip indicated MS.

8.3.1.11 Verify FCP zone and system alarm LEDs are ON.

8.3.1.12 Verify RFAR "Zone "M Fire - Box $3220 "$ received at 200 Area Fire Station.

8.3.1.13 Reset FCP. Verify clear of al arm.

*Denotes zone number in RFAR. 


\begin{tabular}{|c|c|c|c|c|c|}
\hline \multicolumn{6}{|c|}{ DATA SHEET 8.3 .1} \\
\hline \multirow{2}{*}{ STEP } & \multirow{2}{*}{ PERFORM/VERIFY } & \multicolumn{4}{|c|}{ ZONE/MANUAL PULL STATION } \\
\hline & & $2-1$ & $2-2$ & $2-3$ & $2-4$ \\
\hline 8.3 .1 .1 & Open MS. & & & & \\
\hline 8.3 .1 .2 & Close MS. Reset FCP. & & & & \\
\hline 8.3 .1 .3 & Al arm LEDs are OFF. & & & & \\
\hline 8.3 .1 .4 & Lift one wire from MS. & & & & \\
\hline 8.3 .1 .5 & FCP zone trouble LEDs are ON. & & & & \\
\hline 8.3 .1 .6 & Replace wire. & & & & \\
\hline 8.3 .1 .7 & FCP system and FCP zone trouble LEDs are OFF. & & & & \\
\hline 8.3 .1 .8 & Replace MS. & & & & \\
\hline 8.3 .1 .9 & Reset FCP. & & & & \\
\hline 8.3 .1 .10 & Trip MS. & & & & \\
\hline 8.3 .1 .11 & Zone and system LEDs are $\mathrm{ON}$. & & & & \\
\hline 8.3 .1 .12 & Message received at Fire Station. & & NA & NA & NA \\
\hline 8.3 .1 .13 & Reset FCP. & & & & \\
\hline
\end{tabular}


9.1 Audibility Test: This test will verify that signaling devices are adequate for the areas covered.

Perform the following steps.

NOTE: $\quad$ Test to be run during normal operation times. This test may be coordinated with Step 10.1.8.

9.1.1 Trip a manual pull station in Building 338 or place a momentary short between zone terminals.

9.1.2 Verify audible devices are SOUNDING and their signals are clearly heard throughout the building.

9.1.3 Verify strobe lights are flashing.

9.1.4 Reset manual pull station (if used) and FCP.

$9.2 \quad$ Gong Bypass

9.2 .1

At FCP SM-30 Module 3E, turn Gong and Strobe Bypass

disconnect switches to OPERATED. Verify FCP system and SM-30 Module Trouble LEDs are ON.

9.2.2 Trip a manual pull station in Building 338 or place a momentary short between zone terminals.

9.2.3 Verify audible devices are NOT SOUNDING, and strobes are not flashing.

9.2.4 Reset manual pull station (if used) and FCP.

9.2.5 At SM-30 Module 3E, turn Gong and Strobe Bypass disconnect switches to NORMAL. Verify system and SM-30 Module Trouble LEDS are OFF.

9.2.6 Verify FCP system, FCP zone, trouble, and alarm LEDs are OFF. 
BATTERY DRAW DOWN AND POWER TRANSFER: This test will verify battery load and system recharge capability. This test will verify automatic transfer to battery upon ac power interruption and restoration upon return to normal.

10.1 At the panel, perform the following steps.

10.1.1 Disconnect one battery lead. Verify battery trouble LED is ON.

10.1.2 Connect ammeter in battery/panel circuit. Reconnect battery to panel. Verify battery trouble LED is OFF.

10.1.3 At Power Panel AX, open Breaker 25 to interrupt ac power to FCP.

10.1.4 Verify ac power trouble indication. Do not silence trouble buzzer.

10.1.5 At Power Panel AX, open Breaker 27 to interrupt ac power to RFAR.

10.1.6 After 90 second delay, verify "Local Panel Trouble" message followed by "Comm Trb1 RFAR" message for Box 3220 received at 200 Area Fire Station.

10.1.7 Record battery supervisory current. Is = A.

10.1 .8

Put the system into alarm by placing a momentary short between zone terminals or by tripping a manual pull station.

10.1.9 Verify building alarm signaling appliances OPERATE for a minimum of 5 minutes.

10.1.10 Verify alarm message received at 200 Area Fire Station.

10.1.11 Record battery alarm current. Ia $=$ A.

10.1 .12

Silence alarm gongs and trouble buzzer.

10.1.13 Close and secure Breaker 25 and 27.

10.1.14 Remove ammeter from battery circuit, reconnect battery to panel.

10.1.15 Reset the manual pull station (if used). Reset FCP/RFAR.

10.1.16 Verify FCP is in NORMAL condition.

10.1 .17

Verify RFAR is in NORMAL condition. 
10.1 .18

Using the test results obtained in Steps 10.7 and 10.11, calculate the battery requirement using the following formula:

$\left(H_{s} \times I_{s}\right)+\left(H_{a} \times I_{a}\right)=$ Battery requirement in ampere hours $H_{s}=$ hours of standby $(60)$

$H_{a}=$ hours of alarm $(.083)$

$I_{s}=$ standby current in amperes

$I_{a}=$ alarm current in amperes

10.1.18.1 Calculated requirement

$(60 \times$ )$+(.083 x$ )$=$ Ah

10.1 .19

Record the nameplate ampere hour rating of the batteries. Ah.

10.1 .20

Verify the battery requirement calculated is less than the nameplate rating of the batteries. 
Perform the following steps.

11.1 .1

AT ZN-34U2 Module 2D, momentarily short Zone 1 Terminal 2 to - ground.

11.1 .2

Verify system ground fault detection LED is ON momentarily.

11.1 .3

Verify "Local Panel Trouble" message for Box 3220 received at 200 Area Fire Station.

11.1.4 Reset FCP. Verify FCP is in NORMAL condition. 
Perform the following steps.

12.1 .1

Remove RFAR door tamper switch override device.

12.1 .2

Reset FCP. Reset and secure RFAR box.

12.1 .3

Verify FCP and RFAR are in NORMAL condition and secured.

12.1 .4

Verify all detection devices have been reset and are in NORMAL condition.

12.1 .5

Verify all sprinkler system valves are restored to NORMAL condition.

12.1 .6

Depress button on front of RFAR.

12.1 .7

Verify 3 rounds "Fire Front Button Box 3220" received at 200 Area Fire Station.

12.1 .8

Advise 200 Area Fire Station testing is complete.

12.1 .9

Announce to building personnel that test has been completed.

END OF TEST 


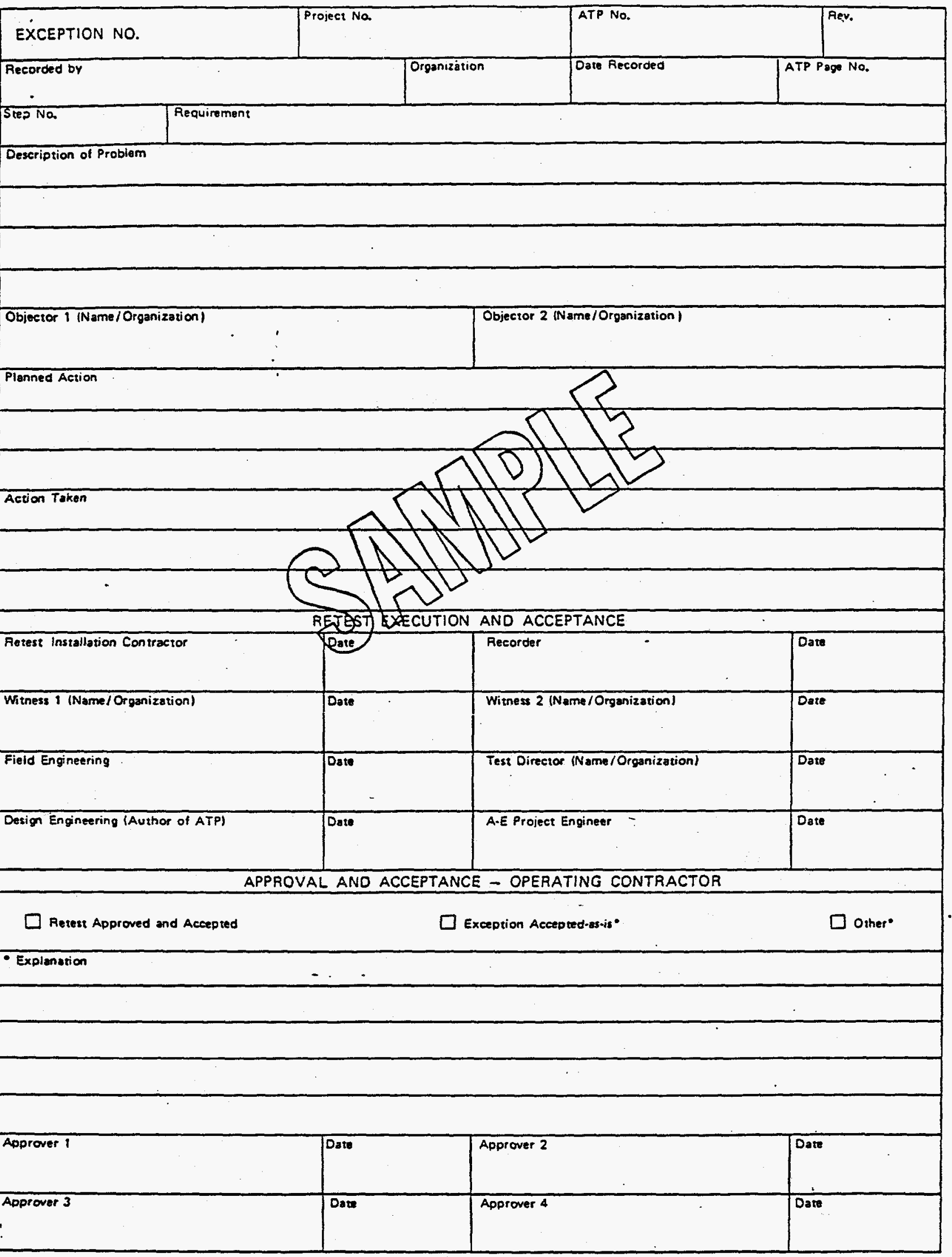

